\title{
The Laramide Mesa Formation and the Ojo de Agua Caldera, Southeast of the Cananea Copper Mining District, Sonora, Mexico
}

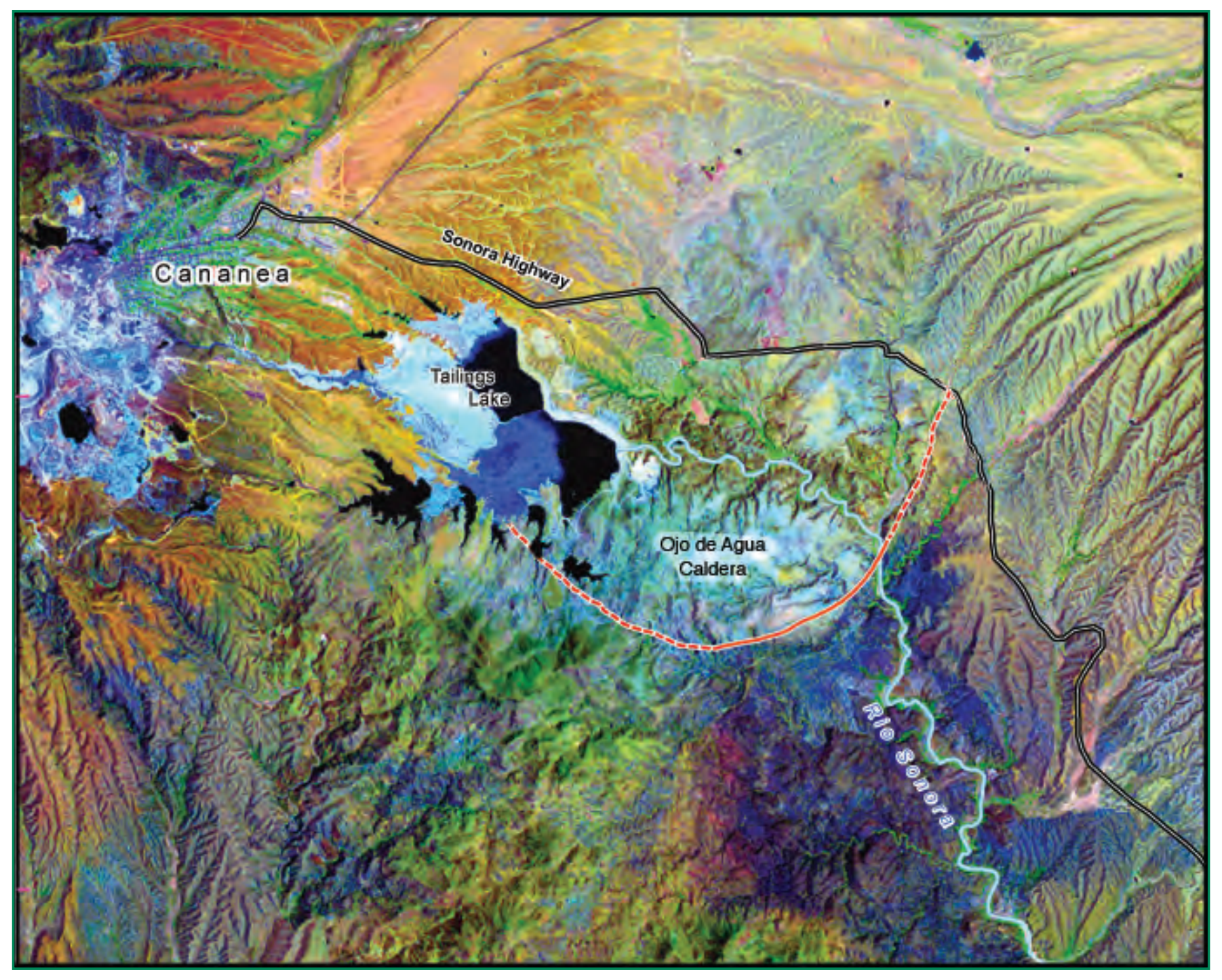

Scientific Investigations Report 2006-5022 


\section{The Laramide Mesa Formation and the 0jo de Agua Caldera, Southeast of the Cananea Copper Mining District, Sonora, Mexico}

By Dennis P. Cox, Robert J. Miller, and Keith L. Woodbourne

Scientific Investigation Report 2006-5022 


\section{U. S. Department of the Interior \\ P. Lynn Scarlett, Acting Secretary}

\section{U.S. Geological Survey \\ P. Patrick Leahy, Acting Director}

\section{U.S. Geological Survey, Reston, Virginia: 2006}

This report and any updates to it are available online at http://pubs.usgs.gov/sir/2006/5022

For product and ordering information:

World Wide Web: http://www.usgs.gov/pubprod

Telephone: 1-888-ASK-USGS

For more information on the USGS--the Federal source for science about the Earth, its natural and living resources, natural hazards, and the environment:

World Wide Web: http://www.usgs.gov

Any use of trade, product, or firm names is for descriptive purposes only and does not imply endorsement by the U.S. Government.

Although this report is in the public domain, permission must be secured from the individual copyright owners to reproduce any copyrighted materials contained within this report.

Cataloging-in-Publication Data are on file with the Library of Congress (URL http://www.loc/gov/)

Produced in the Western Region, Menlo Park, California

Manuscript approved for publication, January 19, 2006

Text edited by James W. Hendley II

Layout and design by Bruce W. Rogers

Cover-Satellite image colored in green and brown tones, showing the area between Cananea and the Sonora River to the east. The El Alacran area is at the lower center of the image. At the center of the image is an area of light blue-gray color that indicates tuff that filled the Ojo de Agua Caldera when it collapsed. The south and east sides of the area has a curved outline (red line) that represents part of the nearly circular outline of the caldera. 


\section{Contents}

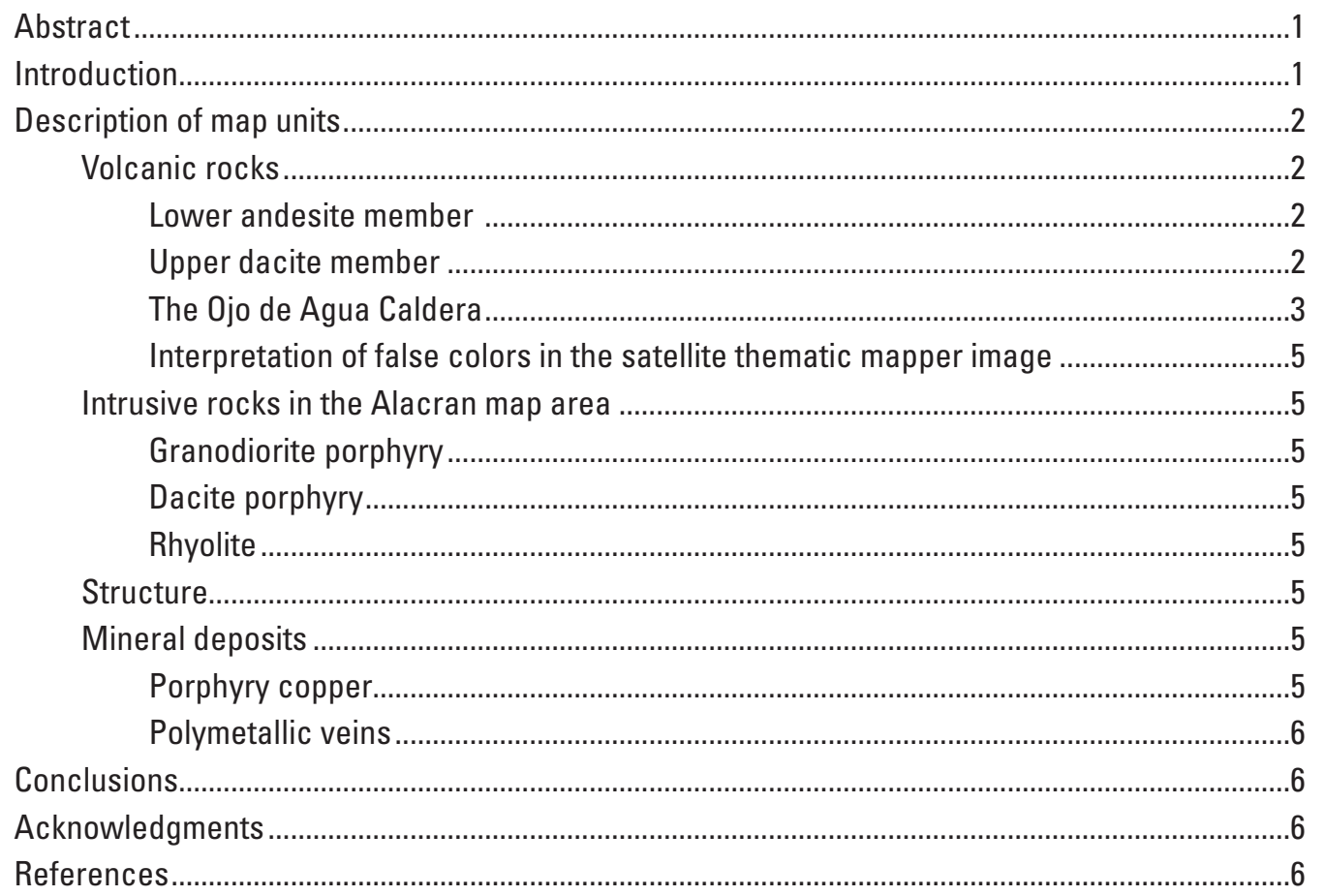

\section{Figures}

1. Location map of study area ..........................................................................................................

2. Location of the Ojo de Agua Caldera and El Alacran in relation to other Cu-Mo porphyry and breccia-pipe deposits and prospects in the Cananea trend of northern Sonora..............2

3. Geologic map of El Alacran and vicinity, Sonora, Mexico ...............................................................3

4. Boundary of the Ojo de Agua Caldera shown on a satellite thematic mapper image of the

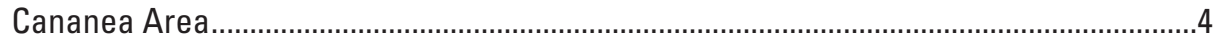

\section{Table}

1. Geochronology of the Mesa Formation east of Cananea, Mexico. 


\title{
The Laramide Mesa Formation and the 0jo de Agua Caldera, Southeast of Cananea Copper Mining District, Sonora, Mexico
}

\author{
By Dennis P. Cox ${ }^{1,2}$, Robert J. Miller, and Keith Woodburne ${ }^{3}$
}

\section{Abstract}

The Mesa Formation extends from Cananea, Mexico, southeast to the Sonora River and is the main host rock of Laramide porphyry copper deposits in the Cananea District and at the Alacran porphyry prospect to the east. The Mesa consists of two members-a lower andesite and an upper dacite. The lowest part of the dacite member is a crystal tuff about $100 \mathrm{~m}$ thick. This tuff is the outfall of a caldera centered near the village of Ojo de Agua, dated by ${ }^{40} \mathrm{Ar} /{ }^{39} \mathrm{Ar}$ at $65.8 \mathrm{Ma} \pm 0.4$. The Ojo de Agua Caldera is about $9 \mathrm{~km}$ in diameter and is filled by a light gray biotite dacite tuff with abundant flattened pumice fragments. The volume of the caldera is estimated to be $24 \mathrm{~km}^{3}$.

\section{Introduction}

The purpose of this report is to announce the discovery of the Ojo de Agua Caldera of Laramide (Upper CretaceousLower Tertiary) age $12 \mathrm{~km}$ east of Cananea, Sonora, Mexico. The caldera is close to the village of Ojo de Agua, named for a system of springs that are the source of the Río Sonora. Our report will also describe the stratigraphy of the Laramide Mesa Formation that contains a tuff unit believed to represent the outfall eruption that resulted from caldera collapse.

The Mesa Formation is the youngest and most extensive of four volcanic formations in the Cananea area. Emmons (1910) referred to this unit as the Mesa tuff but did not identify who named the unit or the type locality. Presumably it is named for the mesa now occupied by the city of Cananea.

The Mesa Formation is the host rock for the El Alacran porphyry copper prospect, located $15 \mathrm{~km}$ southeast of Cananea (figs. 1 and 2). The prospect is part of a 100-km,

\footnotetext{
${ }^{1}$ US Geological Survey, Menlo Park, CA 94025

2 retired, email: dpcox@sbcglobal.net

${ }^{3}$ Address and affiliation unknown
}

northwest-trending line of copper-molybdenum porphyry and breccia-pipe deposits and occurrences (fig. 2). The largest of these are Cananea, with pre mining reserves and resources of 7.1 billion metric tons containing 0.42 percent copper and La Caridad, with 1.8 billion metric tons at 0.45 percent copper (Singer and others, 2005). There are also numerous smaller deposits such as La Florida (Theodore and Priego de Wit, 1976). These deposits, ranging in age from 58 to 49 Ma (Damon and others, 1983) belong to a large province of Laramide volcanic rocks in northern Sonora.

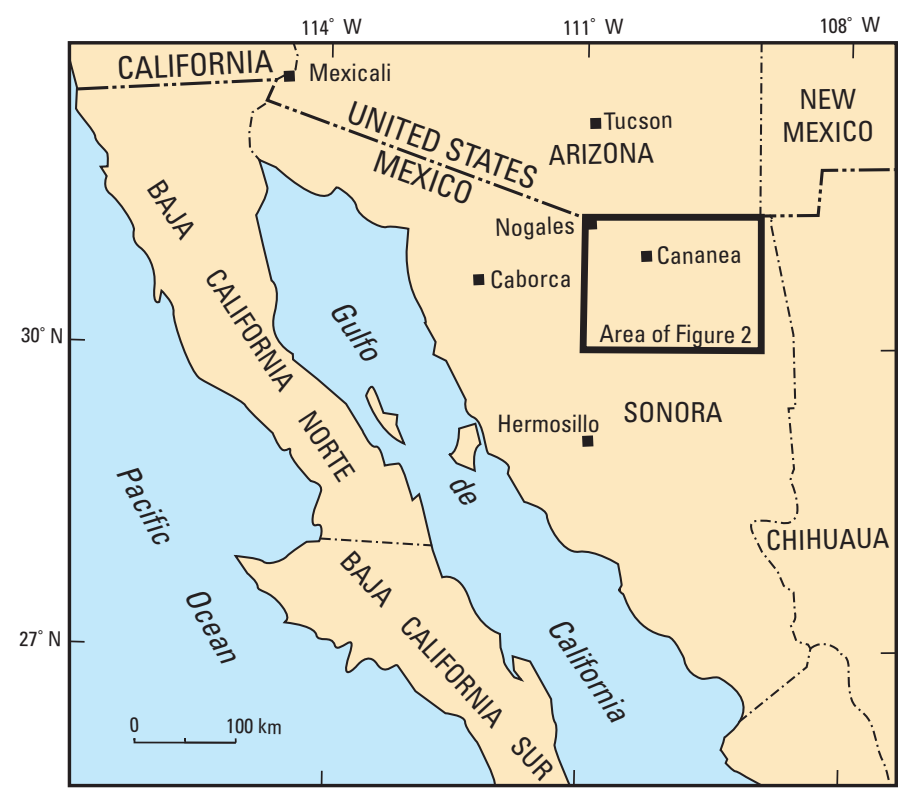

Figure 1. Location of study area.

A broad reconnaissance of these volcanic rocks was part of a cooperative project between the U.S. Geological Survey (USGS) and the National Autonomous University of Mexico under a Memorandum of Understanding signed May 9, 1994. This project was directed by Floyd Gray, USGS, Tucson, Arizona.

The more detailed study leading to this report was carried out to better understand the structural and stratigraphic rela- 


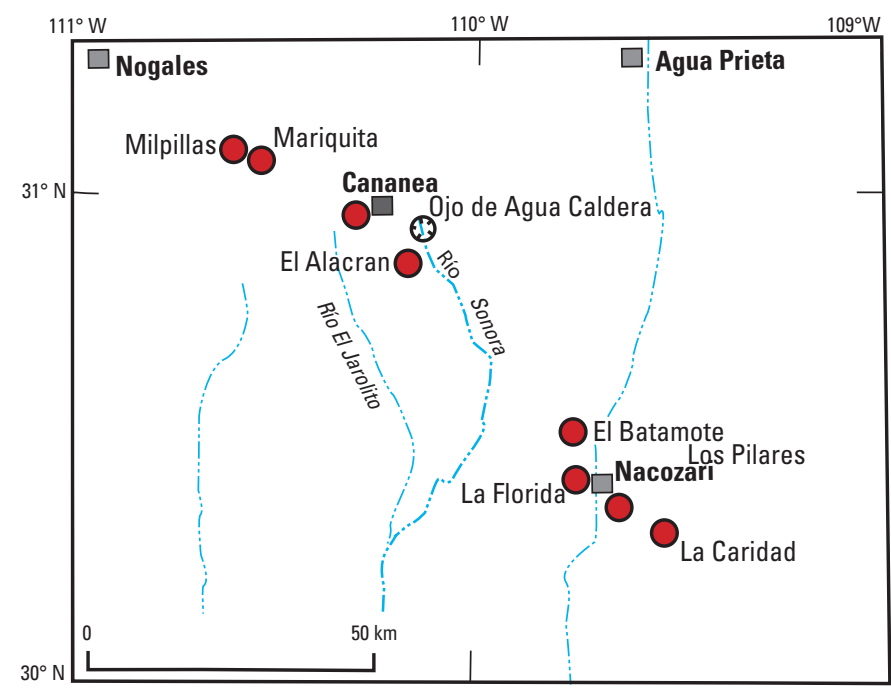

Figure 2. Location of the 0jo de Agua Caldera and El Alcaran in relation to other Cu-Mo porphyry and breccia pipe deposits and prospects in the Cananea trend of northern Sonora. Locations from Singer and others (2005) and Theodore (1976). See figure 1 for location.

tions between two major rock units in the Mesa Formation, here referred to as the lower andesite and upper dacite members. El Alacran was chosen because of good road access and good rock exposures. Geologic mapping at a scale of 1:25,000 of 20 square kilometers surrounding the El Alacran prospect (fig. 3) was done in March and November of 1998.

In 2004, the first author was contracted by Phelps Dodge Exploration Corp. to assist in geologic mapping in a large claim block, surrounding El Alacran. This project was directed by Martin Wiggins and the team consisted of Laurence Barret, Edgar Franco, Victor Espinosa, and Joel Rodriguez. One of the results of this mapping was the discovery of a caldera near the village of Ojo de Agua. The village is named for the springs that are the source of the Río Sonora. Outfall from this caldera formed a prominent tuff unit that lies at the base of the dacite member of the Mesa Formation over a large area between Cananea and the Río Sonora.

\section{Description of Map Units}

The Mesa formation is exposed $3 \mathrm{~km}$ west of the city of Cananea (fig. 4) where it is underlain by the Cretaceous Mariquita diabase and by dacite and latite of the Henrietta Formation (Valentine, 1936). The unit extends southeastward to the Río Sonora, where it is covered by Quaternary deposits. Wodzicki (2001) published an unattributed date of $69.0 \pm 0.2$ Ma for the Mesa formation.

Texture and composition of the volcanic rocks are completely obscured by the illite and kaolin alteration immediately surrounding the El Alacran prospect. Elsewhere in the Alacran map area (fig. 3), moderate to strong propylitic alteration is present. Because of this alteration, no meaningful petrochemical or isotopic studies of the rocks were possible. Petrographic studies of composition and texture were helpful in classifying the volcanic rocks.

\section{Volcanic Rocks}

Two members of the Mesa Formation underlie the Alacran map area - a pyroxene andesite member (Kmaf and Kmai) to the east of the prospect and a younger biotite-bearing dacite member (Kmdt, Kmdb, Kmdw, and Kmdf) to the west. The depositional contact between these units is sharp and dips gently to the west (fig. 3).

${ }^{40} \mathrm{Ar} /{ }^{39} \mathrm{Ar}$ isotopic analysis of biotite from the rhyodacite overlying the Ojo de Agua Caldera fill (fig. 4) gave an ${ }^{40} \mathrm{Ar} /{ }^{39} \mathrm{Ar}$ age of $65.8 \pm 0.4 \mathrm{Ma}$ (F. Gray, unpublished data, 1998) (table 1). Biotite from a dacite tuff-breccia similar to biotite dacite $(\mathrm{Kmdb})$ in the Alacran map area gave an ${ }^{40} \mathrm{Ar} /{ }^{39} \mathrm{Ar}$ age of $72.6 \mathrm{Ma}$ (fig. 3) (F. Gray, written commun., 1998). Veins with sericite alteration cut all volcanic rocks in the map area except the rhyolite (Tr). This alteration is believed to be related to the El Alacran porphyry system which is therefore younger than the Mesa Formation. Damon and others (1983) reported a K/Ar age of 56.7 $\pm 1.2 \mathrm{Ma}$ for biotite from an andesite collected near the El Alacran porphyry. This younger age may reflect resetting of argon due to alteration related to the El Alacran porphyry system. No age data is available for the Ojo de Agua Caldera fill. Its age is probably between 66 and $67 \mathrm{Ma}$.

\section{Lower Andesite Member}

The upper 1,000 $\mathrm{m}$ of the lower andesite member is exposed in the Alacran map area. It has a fragmental texture with sub-rounded andesite clasts set in a dark gray andesitic groundmass. In the east end of the map area, crude flow-stratification is locally prominent. The top of the unit is marked by a $20 \mathrm{~cm}$ layer of thinly layered andesite tuff. At the lowest observed point in the andesite section a $10 \mathrm{~m}$ layer of rhyodacite ignimbrite was noted (fig. 3). It has quartz phenocrysts in a groundmass composed of flattened pumice.

The andesite is composed of plagioclase phenocrysts 2 to $3 \mathrm{~mm}$ long, altered to carbonate and clay minerals and less commonly to albite and $\mathrm{K}$-feldspar. Smaller pyroxene grains are abundant, now largely altered to actinolite, chlorite, and opaque minerals. Where least altered, the anorthite content of the plagioclase phenocrysts ranges from 55 to 68 percent (labradorite). Groundmass textures range from small flowaligned plagioclase laths to fine-grained isotropic material, possibly altered glass Secondary K-feldspar locally replaces the groundmass.

\section{Upper Dacite Member}

The portion of the dacite member that is exposed in the west half of the Alacran area comprises about 1,200 m of 


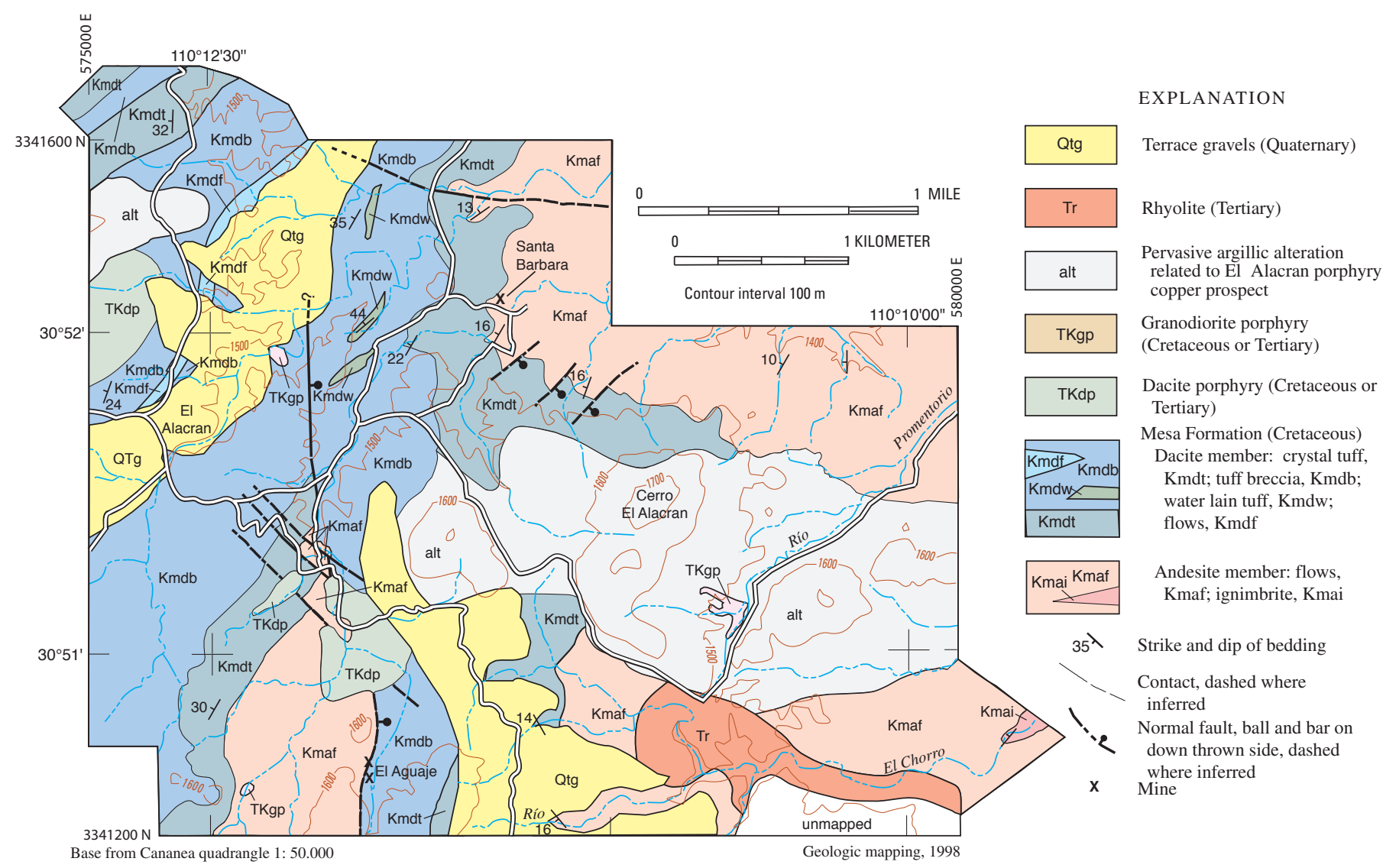

Figure 3. Geologic map of El Alacran and vicinity, Sonora, Mexico.

biotite-bearing tuff-breccia and tuff. Its west-dipping contact with the andesite unit is best exposed near the Santa Barbara mine (fig. 3).

The basal unit of the member is a distinctive crystal tuff, 150 to $200 \mathrm{~m}$ thick, that forms large, blocky, tan-colored outcrops with widely spaced joints (Kmdt). The tuff is well sorted, which suggests an air-fall origin. Reconnaissance mapping shows that this crystal tuff probably represents the outfall from the Ojo de Agua Caldera.

In addition to exposures in the Alacran map area, the crystal tuff forms a prominent questa overlying andesite $3 \mathrm{~km}$ west of Cananea, north of the Cananea mine complex (fig. 4). The tuff is also exposed over a broad area north and south of the Alacran map area. At each exposure the tuff overlies the lower andesite member and grades upward into dacite tuffbreccia. The tuff pinches out to the east and southeast. Figure 4 shows the approximate limit of deposition.

The crystal tuff is composed of 3 to $5 \mathrm{~mm}$ phenocrysts of plagioclase, commonly clustered in aggregates, and having rounded or broken shapes. Plagioclase is everywhere altered to albite or oligoclase and compositional zoning is destroyed. Small biotite phenocrysts have borders blackened by fine-grained magnetite and other opaque minerals. Quartz phenocrysts are rare. The groundmass is composed of fine plagioclase microlites and is locally infiltrated by secondary $\mathrm{K}$-feldspar.
The crystal tuff grades upward into medium- to darkgray tuff-breccia with angular clasts of porphyritic dacite in a dark-gray, fine-grained groundmass. Clasts of granitoid rocks of unknown source are widespread. The tuff-breccia is composed of rounded to broken phenocrysts of plagioclase clustered in aggregates as much as $3 \mathrm{~mm}$ wide. Where least altered, the anorthite content of plagioclase ranges widely from $\mathrm{An}_{40}$ (andesine) to $\mathrm{An}_{60}$ (labradorite) suggesting mixing of phenocrysts from different magmatic sources. Small euhedral biotite phenocrysts are ubiquitous. Hornblende and quartz phenocrysts are rare. The groundmass is composed mainly of small plagioclase laths, commonly flow-aligned, in a dark isotropic matrix.

About $800 \mathrm{~m}$ above the base of the upper dacite member are discontinuous beds of dark-gray, water-laid tuff associated with 10-cm pillow-like structures in the adjacent dacite flows (Kmdb). To the west $1.5 \mathrm{~km}$, compact dacite flows without the characteristic breccia texture were recognized (Kmdf). Higher in the Mesa formation, west of the Alacran map area, rhyodacite tuff was locally deposited in beds 10 to $50 \mathrm{~m}$ thick.

\section{The Ojo de Agua Caldera}

Caldera-fill tuff is well exposed along the Sonora highway between UTM 580,500 and 582,200 E and along the canyon walls of the upper reaches of the Río Sonora (fig. 4). 


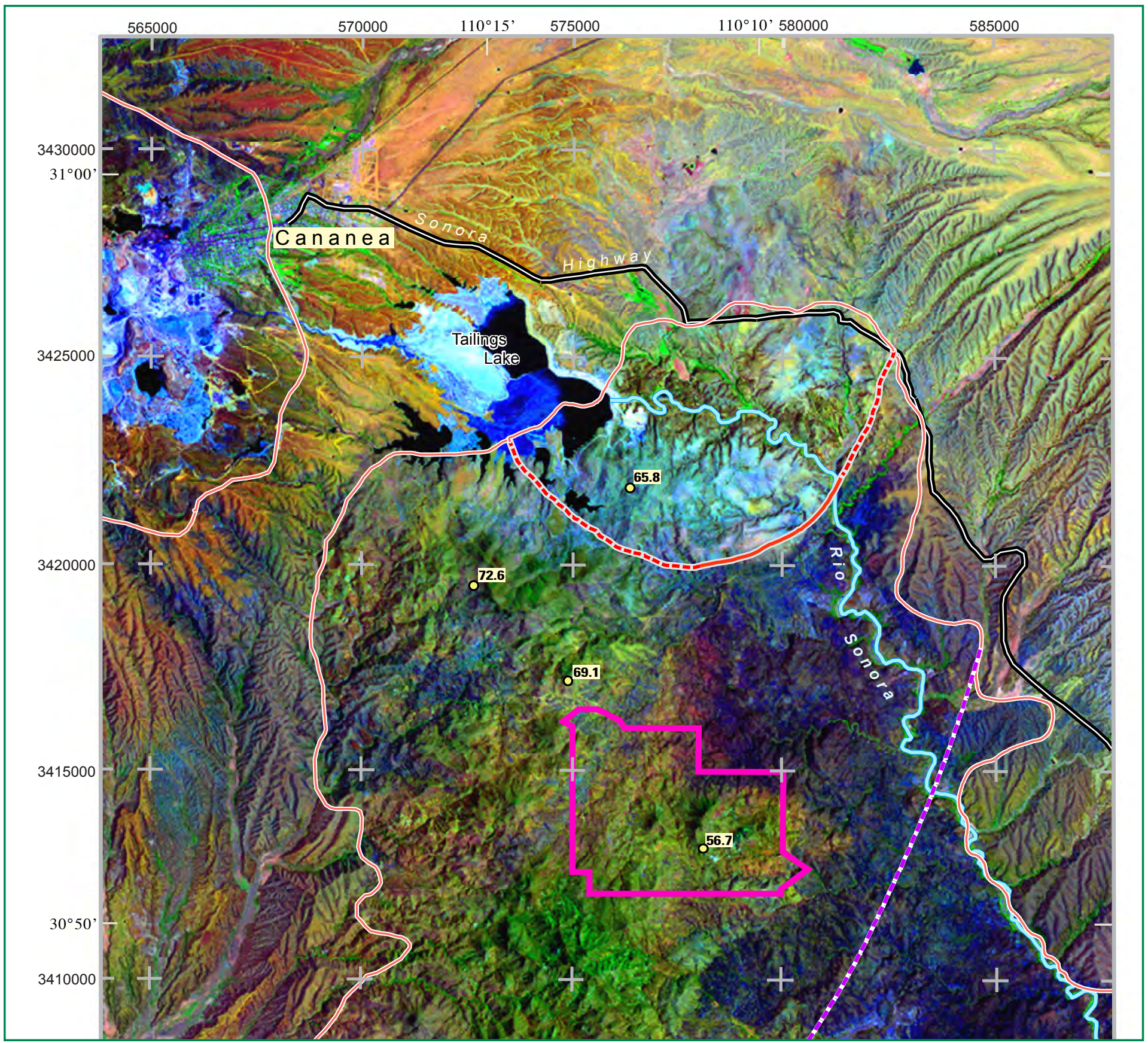

\section{EXPLANATION}

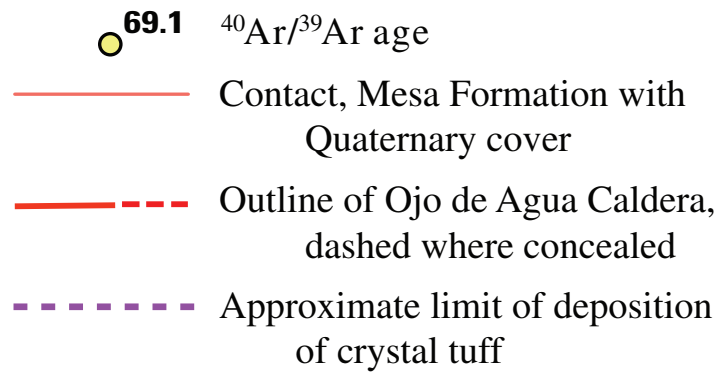

Outline of figure 3

False color image using bands 2,4, and 7 from Landsat Thematic Mapper scene Path 35, Row 38 acquired Nov. 13, 1999.

0 1 23

Figure 4. Boundary of the Ojo de Agua caldera shown on a satellite thematic mapper image of the Cananea area. 
The quarry, which provides the rock materials for the tailings dam west of Ojo de Agua, is also a part of the caldera fill. It is well lithified, light gray to pale tan in color, and is composed of fine crystals of intermediate plagioclase, minor biotite, and rock fragments generally less than $1 \mathrm{~cm}$ in diameter. The matrix is holocrystalline. Flattened pumice fragments 5 to $10 \mathrm{~cm}$ in diameter are prominent along the upper Sonora River and near the pumping station on the Tailings Lake to the west. Locally, steeply dipping, parallel joints are abundant. The joints are regularly spaced 5 to $10 \mathrm{~cm}$ apart, and the joint sets occupy areas 100 to $200 \mathrm{~m}$ wide. There seems to be no relation between the strike of these joint sets and any regional fault patterns.

The north half of the caldera is covered by alluvium. To the south the caldera fill is in contact with tuff-breccia of the upper dacite member along a smooth, sharply defined curve, concave to the north. The contact dips steeply to the north toward the center of the caldera. The southwest portion of the contact is concealed by talus gravels and, to the east by thin discontinuous flows of rhyodacite. These flows presumably represent the final stages of caldera eruption (see table 1). The diameter of the caldera is approximately $9 \mathrm{~km}$.

\section{Interpretation of False Colors in the Satellite Thematic Mapper Image}

Figure 4 correctly shows lighter tones to the west of El Alacran in the area underlain by the dacite member of the Mesa Formation. To the east of El Alacran, and along the Río Sonora, the darker tones suggest that the area is underlain by the darker colored andesite member. Mapping in 2004 however, showed that this is not the case. Although andesite outcrops are widespread, much of the area is covered by the younger dacite. Because these colors record vegetation differences as well as rock types, the dark tones may reflect greater abundance of water in the valley of the Río Sonora.

To the north, the caldera fill and rhyodacite tuff are clearly shown by the light gray tones. Tailings from the Cananea mine complex produce the white area west of the lake.

\section{Intrusive Rocks in the Alacran Map Area}

\section{Granodiorite Porphyry}

A granodiorite porphyry intrusion (TKgp) is exposed in the headwaters of Río Promentorio in the deeply eroded central part of the El Alacran alteration area (fig. 3). It has closely spaced phenocrysts of sericitized feldspar, biotite, and quartz surrounded by a microaplitic quartz-feldspar groundmass. The porphyry is cut by a stockwork of quartz veinlets.

\section{Dacite Porphyry}

Irregular dacite porphyry intrusions (TKdp) having the same mineral composition as the dacite volcanic unit are common in the southwestern parts of the map area. These rocks have small inclusions of volcanic rocks but lack the fragmental texture of the volcanic dacite. The groundmass of this porphyry is composed of randomly oriented, small, feldspar laths. The rocks show no evidence of hydrothermal alteration. Contact relations indicate that the dacite porphyry is younger than the normal and strike-slip faulting in the southwest part of the map area. These dacite intrusions are possibly representative of various volcanic centers contributing to the upper part of the dacite member.

\section{Rhyolite}

A large mass of rhyolite (Tr) crops out along the Río El Choro in the southeast part of the map area. Its north contact with andesite, exposed in El Choro canyon, is vertical, and for this reason the rhyolite is believed to be an intrusion. It is composed of 2-mm wide quartz phenocrysts set in a fine-grained quartz-feldspar matrix, probably derived from devitrification of glass. Locally the rhyolite contains dark gray spherulites 1 $\mathrm{cm}$ in diameter. This rock is assigned a tentative Tertiary age because it is unaffected by the Early Tertiary alteration related to the nearby El Alacran porphyry system.

\section{Structure}

The Mesa Formation has a regional tilt of 15 degrees to the east-northeast in the Cananea area (Valentine, 1936; Wodzicki, 2001). In the Alacran map area, the Mesa dips 13 to 35 degrees to the west-northwest.

Normal faults striking northeast with the southeast side dropped down, and north with the east side down are the major structures. The north-trending fault, located in the south central part of the map area near the El Aguaje mine, produced a $750 \mathrm{~m}$ displacement of the dacite-andesite contact (east side down). This fault was intruded by dacite porphyry and cut by northwest-striking faults with small strike-slip displacement.

\section{Mineral Deposits}

\section{Porphyry Copper}

The El Alacran porphyry copper prospect has been described by Alarcón and others (1973) and Dean (1975). Its surface expression is a west-northwest-trending area of intense illite and kaolin alteration 1 by $3 \mathrm{~km}$ in size. Near the center is a small granodiorite porphyry exposure with quartz- vein stockwork. Elsewhere the altered rocks appear to be volcanic. It was not possible to recognize the two volcanic units within the alteration area.

Steeply dipping, tabular bodies of quartz-kaolinite that are abundant near the border of the alteration zone represent a late-stage advanced argillic alteration. These bodies are resistant to erosion and support El Alacran Mountain and other peaks surrounding the prospect. 
Table 1. Geochronology of the Mesa Formation east of Cananea, Mexico.

\begin{tabular}{|c|c|c|c|c|}
\hline Location (UTM) & Rock type & Age, Ma & Method & Reference \\
\hline $\begin{array}{l}572635 \mathrm{E} \\
3419487 \mathrm{~N}\end{array}$ & $\begin{array}{l}\text { Dacite tuff } \\
\text { breccia }\end{array}$ & $72.6 \pm 1.2$ & $\begin{array}{c}{ }^{40} \mathrm{Ar} /{ }^{36} \mathrm{Ar} \\
\text { biotite }\end{array}$ & $\begin{array}{l}\text { F. Gray, written } \\
\text { commun., } 1998\end{array}$ \\
\hline $\begin{array}{l}574863 \mathrm{E} \\
3417160 \mathrm{~N}\end{array}$ & $\begin{array}{c}\text { Dacite tuff } \\
\text { breccia }\end{array}$ & $69.1 \pm 0.4$ & $\begin{array}{c}{ }^{40} \mathrm{Ar} /{ }^{36} \mathrm{Ar} \\
\text { biotite }\end{array}$ & $\begin{array}{l}\text { F. Gray, written } \\
\text { commun., } 1998\end{array}$ \\
\hline $\begin{array}{l}576331 \mathrm{E} \\
3421872 \mathrm{~N}\end{array}$ & $\begin{array}{l}\text { Rhyodacite } \\
\text { tuff }\end{array}$ & $65.8 \pm 0.4$ & $\begin{array}{c}{ }^{40} \mathrm{Ar} / 36 \mathrm{Ar} \\
\text { biotite }\end{array}$ & $\begin{array}{l}\text { F. Gray, written } \\
\text { commun., } 1998\end{array}$ \\
\hline $\begin{array}{l}573087 \mathrm{E} \\
3413081 \mathrm{~N}\end{array}$ & $\begin{array}{l}\text { Andesite, } \\
\text { altered }\end{array}$ & $56.7 \pm 1.2$ & $\begin{array}{c}\mathrm{K} / \mathrm{Ar} \\
\text { biotite }\end{array}$ & $\begin{array}{l}\text { Damon and } \\
\text { others (1983) }\end{array}$ \\
\hline
\end{tabular}

Our reconnaissance failed to find copper-oxide minerals or signs of development of a leached capping. It is possible that exposures at El Alacran, including the quartz-kaolinite bodies, represent the uppermost levels of the system and that copper mineralization could increase with depth.

\section{Polymetallic Veins}

Numerous veins of quartz and (or) chalcedony with sericite alteration halos are abundant in the map area. The most important of these have been developed as small mines at El Aguaje and Santa Barbara. At El Aguaje two vertical shafts are aligned along the north-trending normal fault described above. Samples of comb-structured quartz with pyrite, sphalerite, and galena were found on the dump. At Santa Barbara a small shaft was sunk on a N. $60^{\circ} \mathrm{W}$. silicified zone in sericitized dacite. No ore samples were found on the mine dump.

\section{Conclusions}

The oldest rock unit in the Alacran map area is the lower andesite member of the Mesa formation. A large dacite cone was constructed on the andesite member. Pyroclastic eruption from this cone produced an airfall crystal tuff up to 200 $\mathrm{m}$ thick that covered an area of at least 240 square $\mathrm{km}$. If the average thickness is $100 \mathrm{~m}$, the volume of tuff would be 24 cubic $\mathrm{km}$. Collapse of the cone produced a caldera $9 \mathrm{~km}$ in diameter with an area of $28 \mathrm{~km}^{2}$. An assumed depth of collapse of $850 \mathrm{~m}$ would have produced $24 \mathrm{~km}^{3}$. of tuff. This caldera is roughly equivalent in diameter to the Crater Lake Caldera in southern Oregon, but smaller in outfall volume.

Continuing dacite volcanism from various centers produced an unknown thickness of tuff-breccia, tuffs, and flows overlying the crystal tuff. Minor rhyodacite tuff was deposited in the upper part of the dacite member.
Porphyry mineralization at El Alacran caused widespread alteration of the Mesa formation and peripheral veins at Santa Barbara and El Aguaje. The porphyry system may be related to the later stages of dacite volcanism.

Faults in the Alacran area mainly trend east-northeast and north-south. The only reflection of the regional northwest trend of $\mathrm{Cu}-\mathrm{Mo}$ deposits shown in figure 2 is the west-northwest elongation of parts of the El Alacran alteration zone shown in figure 4 , the N. $60^{\circ} \mathrm{W}$. strike of the Santa Barbara vein, and the presence of a body of phyllic alteration on the west border of the map lying $\mathrm{N} .60^{\circ} \mathrm{W}$. from the main porphyry prospect.

\section{Acknowledgments}

We gratefully acknowledge the cooperation of Remigio Martinez and Juan Correa of Cananea Copper Mining Company. We also enjoyed the hospitality shown to us by the Raspón, Ruiz, and Torres families and other ranchers in the area. Geologists at the BHP exploration office in Tucson, Arizona, kindly let us use their infrared mineral analyzer to identify alteration minerals. Thanks are due to Diego Fernandez of Teck Cominco American, Inc. and Martin Wiggins of Phelps Dodge Exploration Corp. for permission to publish data from the Maria 47 mapping project. Barry Moring (USGS) assisted in preparation of figure 3, and Robert Christiansen, Moring, Victor Mossotti, and Ted Theodore (USGS) contributed helpful reviews of the report.

\section{References}

Alarcón, Ubaldo, Aguilera, Eduardo, and López Avila, Javier, 1973, Informe sobre los estudios geologicos, geoquimicos y geofisicos en el prospecto El Alacran, Sonora hasta Marzo de 1970: Consejo de Recursos Naturales No Renovables, Bol. 79, p. 49-80. 
Damon, P.E., Shafiquilah, Muhammud, and Clark, K.F., 1983, Geochronology of porphyry copper deposits and related mineralization of Mexico: Canadian Journal of Earth Sciences, v. 20, p. 1052-1071.

Dean, D.A., 1975, Geology, alteration, and mineralization of the El Alacran area, Northern Sonora, Mexico: University of Arizona, Master's Thesis, 222 p.

Emmons, S.F., 1910, Cananea Mining District of Sonora Mexico: Economic Geology, v. 5, p. 312-356.

Singer, D.A., Berger, V.I., and Moring, B.C., 2005, Porphyry copper deposits of the World-database, map, and grade and tonnage models: U.S. Geological Survey Open-File Report 05-1006.
Theodore, T.G., and Priego de Wit, Miguel, 1976, Porphyry-type metallization and alteration at La Florida de Nacozari: U.S. Geological Survey Open-File Report 76-760, $28 \mathrm{p}$.

Valentine, W.G., 1936, Geology of the Cananea Mountains, Sonora, Mexico: Geological Society of America, v. 47, p.53-86.

Wodzicki, W.A., 2001 The Evolution of magmatism and mineralization in the Cananea District, Sonora Mexico, in Albinson, Tawn, and Nelson, C.E., eds. New mines and discoveries in Mexico and Central America: Economic Geology Special Publication Number 8, p. 243263. 